\title{
Different Effects on Inhibition of Cardiac Hypertrophy in Spontaneously Hypertensive Rats by Monotherapy and Combination Therapy of Adrenergic Receptor Antagonists and/or the Angiotensin II Type 1 Receptor Blocker under Comparable Blood Pressure Reduction
}

\author{
Takae ASAI, Toshio KUSHIRO, Hirotaka FUJITA, and Katsuo KANMATSUSE
}

\begin{abstract}
To confirm that $\alpha 1, \beta$ adrenoceptor antagonists and angiotensin II type 1 receptor blockers (ARBs) have different abilities to attenuate progressive cardiac hypertrophy despite their comparable lowering of blood pressure, we compared the effect of these agents alone or in combination on hypertensive cardiac hypertrophy. Eight-week-old spontaneously hypertensive rats (SHR) were divided into 7 groups. Single administration of doxazosin, atenolol, or losartan, or half-dose combinations of these drugs were given orally for 6 weeks. The control group did not receive any drugs. The heart weight-to-body weight ratio (HW/BW), left ventricular mass index (LVMI), plasma brain natriuretic peptide (BNP) and left ventricular BNP mRNA expression were measured after 6-week administration. Blood pressure did not differ among the drugtreated groups, all of which showed lower blood pressure than the control group. The HW/BW and LVMI of the drug-treated groups, except the doxazosin group, were lower than in the control group. Moreover, the LVMI values of the groups receiving losartan were significantly lower than those in the groups without losar$\tan (p<0.05)$. Plasma BNP of the drug-treated groups was lower than that in the control group $(p<0.05)$. The left ventricular BNP mRNA expression of the drug-treated groups, except the doxazosin group, was lower than that in the control group. The atenolol group showed a higher level of BNP mRNA than the groups receiving losartan monotherapy or combination therapies $(p<0.05)$. In conclusion, the ARB had the strongest attenuating effect on the development of hypertensive cardiac hypertrophy, and the $\alpha 1$ and $\beta$ adrenergic receptor blockers were more effective in combination than as monotherapies in SHR. (Hypertens Res 2005; 28: 79-87)
\end{abstract}

Key Words: cardiac hypertrophy, hypertension, angiotensin II type 1 receptor blocker, adrenergic receptor antagonists, combination therapy

\section{Introduction}

As antihypertensive treatment has become increasingly common, the cardiovascular risks associated with hypertension have declined. As a result, stroke incidence has also decreased, and cardiac hypertrophy and its progression to heart failure now have a serious influence on life prognosis and quality of life. Cardiac hypertrophy is also an independent risk factor for ischemic heart diseases, arrhythmia, sudden death, and other problems (1). Therefore, antihypertensive treatments should aim not only to lower blood pressure but also to prevent target organ damage. In particular, treatments with preventive or regressing effects on cardiac hyper-

From the Division of Cardiovascular Medicine, Department of Medicine, Nihon University School of Medicine, Tokyo, Japan.

Address for Reprints: Takae Asai, M.D., Department of Cardiology, Surugadai Nihon University Hospital, 1-8-13, Kandasurugadai, Chiyoda-ku, Tokyo 101-8309, Japan. E-mail: asait@med.nihon-u.ac.jp

Received August 6, 2004; Accepted in revised form October 12, 2004. 
Table 1. Oligonucleotide Primer Sequences and Cycling Conditions of BNP and GAPDH for the Quantitative Real Time Polymerase Chain Reaction

\begin{tabular}{|c|c|c|c|c|c|c|c|}
\hline mRNA & $\begin{array}{l}\text { Reference } \\
\text { number }\end{array}$ & Primer sequence & $\begin{array}{l}\text { Product } \\
\text { size (bp) }\end{array}$ & $\begin{array}{c}\text { Denaturation } \\
\text { temp. } \\
\left({ }^{\circ} \mathrm{C}\right) / \text { time }(\mathrm{s})\end{array}$ & $\begin{array}{l}\text { Annealing } \\
\text { temp. } \\
\left({ }^{\circ} \mathrm{C}\right) / \text { time }(\mathrm{s})\end{array}$ & $\begin{array}{l}\text { Extension } \\
\text { temp. } \\
\left({ }^{\circ} \mathrm{C}\right) / \text { time }(\mathrm{s})\end{array}$ & $\begin{array}{c}\text { Cycle } \\
\text { number }\end{array}$ \\
\hline BNP & 24 & $\begin{array}{l}\text { F: 5'-CTGGGAAGTCCTAGCCAGTCTCCA-3' } \\
\text { R: 5'-GCGACTGACTGCGCCGATCCGGTC-3' }\end{array}$ & 250 & $93 / 30$ & $53 / 30$ & $73 / 60$ & 30 \\
\hline GAPDH & 25 & $\begin{array}{l}\text { F: 5'-AGATCCACAACGGATACATT-3' } \\
\text { R: 5'-TCCCTCAAGATTGTCAGCAA-3' }\end{array}$ & 305 & $94 / 60$ & $\begin{array}{l}65 / 60 \\
60 / 60\end{array}$ & $72 / 180$ & 30 \\
\hline
\end{tabular}

BNP, brain natriuretic peptide; GAPDH, glyceraldehyde-3-phosphate-dehydrogenase; F and R stand for forward and reverse primers, respectively, in $5^{\prime} \rightarrow 3^{\prime}$ orientation; bp, base pairs; temp., temperature.

trophy are desirable.

The mechanism by which cardiac hypertrophy develops involves both mechanical and neurohumoral factors $(2,3)$. Mechanical factors induce hypertrophy of myocytes, interstitial fibrosis, and collagen accumulation. Neurohumoral factors include angiotensin II, catecholamine, endothelin, and cytokines.

The sympathetic nervous system (SNS) and the renin angiotensin system (RAS) are both believed to be related to the development of cardiac hypertrophy (4-8). Norepinephrine has been reported to induce cardiac hypertrophy through $\alpha 1$ adrenergic receptors (9) and to induce cardiac hypertrophy through $\beta$ adrenergic receptors in cultured cardiomyocytes (4). There have also been reports of intrinsic catecholamineproducing cells in the heart (10). Angiotensin II accelerates myocardial hypertrophy and collagen accumulation through angiotensin II type 1 (AT1) receptors $(11,12)$. The presence of tissue RAS has been identified in several organs (13), and it may contribute to cardiac hypertrophy $(6,7)$.

Suppression of $\alpha 1$ and $\beta$ adrenergic receptors, and AT1 receptors, is believed to inhibit the progress of cardiac hypertrophy. However, in antihypertensive treatment with selective receptor blockers, intrinsic agonists that are increased through feedback mechanisms may influence receptor function that is not affected by antagonists. For example, catecholamines increased by the $\alpha 1$ adrenergic receptor antagonist may stimulate unopposed $\beta$ adrenergic receptors. Consequently, a better antihypertrophic effect is expected by suppressing several systems simultaneously by combined administration of both SNS and RAS receptor blockers. It has been reported that the antihypertrophic effect differs according to the class of antihypertensive agent $(14,15)$. Moreover, combination therapies have been shown to confer better protection against cardiac hypertrophy than monotherapies $(16,17)$. However, there is a dearth of information on which classes of antihypertensive agents in what combination are preferable.

Brain natriuretic peptide (BNP) has been shown to be a marker of cardiac hypertrophy $(18,19)$ and a risk factor for cardiovascular events in hypertension (20). However, there have been few reports comparing the cardiac antihypertrophic effect, in connection with BNP, between monotherapy and combination therapy under comparable blood pressure reduction. The present study examined the effects of $\alpha 1, \beta$ adrenergic receptor antagonists and the AT1 receptor blocker (ARB), alone or in combination, on the development of cardiac hypertrophy under comparable blood pressure reduction in spontaneously hypertensive rats (SHR).

\section{Methods}

\section{Materials and Experimental Design}

We followed the Guidelines for Animal Experimentation of the Nihon University School of Medicine. Eight-week-old male SHR (Funabashi Farm, Chiba, Japan) were exposed to a 12 -h environmental light cycle, $24^{\circ} \mathrm{C}$ temperature, and $40 \%$ humidity with free access to standard rat food (Oriental Yeast Co., Ltd., Tokyo, Japan) and tap water in individual cages for the 6-week experimental period.

Doxazosin (Pfizer Inc., New York, USA) was used as an $\alpha 1$ adrenergic receptor blocker, atenolol (Sigma-Aldrich Co., St. Louis, USA) as a $\beta$ blocker, and losartan (Banyu Pharmaceutical Co., Ltd., Tokyo, Japan) was used as an ARB. The doxazosin was donated by Pfizer Inc. and the losartan was a gift of Banyu Pharmaceutical Co., Ltd.

Doxazosin was mixed with drinking water. Atenolol and/or losartan were mixed with drinking water in single administration and with food in combined administration. The drug concentration for each rat was calculated based on the mean intake of food and water and mean body weight over 2 days, so as to give the target dose.

Seventy-two male SHR were divided into 7 groups as follows. The control group (C group, $n=9$ ) received purified water and normal rat food only. The monotherapy groups were administered doxazosin $10 \mathrm{mg} / \mathrm{kg}$ /day (DXZ group, $n=11$ ), atenolol $20 \mathrm{mg} / \mathrm{kg} /$ day (ATN group, $n=11$ ), or losar$\tan 10 \mathrm{mg} / \mathrm{kg} /$ day (LST group, $n=12$ ), respectively. The 2drug combination groups were administered doxazosin $5 \mathrm{mg}$ / $\mathrm{kg} /$ day and atenolol $10 \mathrm{mg} / \mathrm{kg} /$ day $(\mathrm{DXZ}+\mathrm{ATN}$ group, $n=9)$, or doxazosin $5 \mathrm{mg} / \mathrm{kg} /$ day and losartan $5 \mathrm{mg} / \mathrm{kg} /$ day (DXZ +LST group, $n=11$ ), respectively. The 3-drug combination group received doxazosin $5 \mathrm{mg} / \mathrm{kg} /$ day, atenolol 10 
Table 2. Body Weight, Systolic Blood Pressure, and Pulse Rate of Untreated Spontaneously Hypertensive Rats (SHR) and SHR Treated with Monotherapy and Combination Therapy by Doxazosin, Atenolol, and/or Losartan for 6 Weeks

\begin{tabular}{lccccccc}
\hline & \multicolumn{1}{c}{$\begin{array}{c}\text { CNT } \\
(n=9)\end{array}$} & \multicolumn{1}{c}{$\begin{array}{c}\text { DXZ } \\
(n=11)\end{array}$} & $\begin{array}{c}\text { ATN } \\
(n=11)\end{array}$ & $\begin{array}{c}\text { LST } \\
(n=12)\end{array}$ & $\begin{array}{c}\text { DXZ+ATN } \\
(n=9)\end{array}$ & $\begin{array}{c}\text { DXZ+LST } \\
(n=11)\end{array}$ & $\begin{array}{c}\text { DXZ+ATN+LST } \\
(n=9)\end{array}$ \\
\hline BW (g) & $320.5 \pm 4.0$ & $318.0 \pm 6.2$ & $316.2 \pm 1.9$ & $310.4 \pm 6.2$ & $309.8 \pm 8.4$ & $321.6 \pm 3.6$ & $317.8 \pm 4.4$ \\
SBP (mmHg) & $202.2 \pm 5.9$ & $184.8 \pm 3.1^{*}$ & $184.0 \pm 2.4^{*}$ & $178.7 \pm 3.3^{*}$ & $184.2 \pm 2.6^{*}$ & $179.8 \pm 2.4^{*}$ & $180.0 \pm 2.8^{*}$ \\
PR (bpm) & $384.1 \pm 8.2$ & $379.3 \pm 10.6$ & $337.3 \pm 3.5^{*,+, \S}$ & $388.4 \pm 7.3$ & $347.0 \pm 5.0^{*,+, \S}$ & $354.2 \pm 6.9$ & $338.4 \pm 7.5^{*,+, \S}$ \\
\hline
\end{tabular}

Values are expressed as the means \pm SEM. BW, body weight; SBP, systolic blood pressure; PR, pulse rate; bpm, beat per minute; CNT, control; DXZ, doxazosin; ATN, atenolol; LST, losartan; DXZ+ATN, combination of doxazosin and atenolol; DXZ+LST, combination of doxazosin and losartan; DXZ+ATN+LST, combination of doxazosin, atenolol, and losartan. ${ }^{*} p<0.05 v s . \mathrm{CNT}$; ${ }^{\dagger} p<0.05 v s$. DXZ; ${ }^{\S} p<0.05$ vs. LST.

$\mathrm{mg} / \mathrm{kg} /$ day, and losartan $5 \mathrm{mg} / \mathrm{kg} /$ day $(\mathrm{DXZ}+\mathrm{ATN}+\mathrm{LST}$ group, $n=9$ ).

Previous studies using SHR have reported that $10 \mathrm{mg}$ of doxazosin reduced blood pressure approximately $60 \mathrm{mmHg}$, $50 \mathrm{mg}$ of atenolol reduced blood pressure $40 \mathrm{mmHg}$, and 10 $\mathrm{mg}$ of losartan lowered blood pressure $40 \mathrm{mmHg}(21,22)$. To achieve an equivalent blood pressure-lowering effect with these antihypertensive agents, a pilot study was conducted. Ten mg of doxazosin was administered orally and found to decrease blood pressure approximately $20 \mathrm{mmHg}$, and both $20 \mathrm{mg}$ of atenolol and $10 \mathrm{mg}$ of losartan also lowered blood pressure to the same extent, respectively. Similarly, it was confirmed that the combinations of a half dose of doxazosin and a half dose of either or both of the other two drugs reduced blood pressure to the same degree.

\section{Measurement of Body Weight (BW), Systolic Blood Pressure (SBP), and Pulse Rate (PR)}

BW was measured weekly in the morning throughout the 6week administration period, together with SBP and PR by the tail-cuff method using a Rat Tail Manometer Tachometer System (KN-210-1; Natsume Seisakusho, Tokyo, Japan).

\section{Measurement of Left Ventricular Mass Index (LVMI) by Echocardiography}

Echocardiographic studies (Aloka Echo Camera SSD-1200; Aloka Co., Ltd., Tokyo, Japan) were performed with a 7.5MHz probe (UST 957-7.5; Aloka Co., Ltd.) under anaesthesia after shaving of the rat's chest. Measurements were performed before drug administration (at 8 weeks of age) and at the end of the 6-week administration period (at 14 weeks of age). Interventricular septum wall thickness, posterior wall thickness, and left ventricular end diastolic dimension were all measured using M-mode long-axis imaging. LVMI was calculated after the measurements by the Devereux method (23) and adjusted by body weight.

\section{Measurement of Plasma BNP (pBNP) and Angio- tensin II}

After measurement of blood pressure at the end of the administration period, a catheter (PE-50; Becton and Dickinson Co., Franklin Lakes, USA) was inserted into the right carotid artery under ether anaesthesia and was subcutaneously fixed to the skin between the scapulas. Twenty-four hours after fixing of the catheter, pBNP (immunoradiometric assay) and angiotensin II (double antibody radioimmunoassay) were measured in the blood sample collected through the catheter.

\section{Measurement of the Heart Weight-to-Body Weight Ratio (HW/BW)}

After blood collection and extraction and weighing of the heart, HW/BW was calculated.

\section{Measurement of Left Ventricular BNP mRNA Expression by Quantitative Real-Time Poly- merase Chain Reaction (PCR)}

After the heart was weighed, the left ventricle was cut at the papillary muscle level, and its apex was frozen with liquid nitrogen. Total RNA was extracted and left ventricular BNP mRNA expression was examined by quantitative real-time PCR assay with SYBR Green Reagents (Applied Biosystems, Foster City, USA). Table 1 shows the primer sequences and PCR conditions of each gene used in this study $(24,25)$.

\section{Extraction of RNA}

One hundred $\mathrm{mg}$ of myocardial tissue was homogenized in 1 ml Trizol Reagent (Molecular Research Center Inc., Cincinnati, USA) and $2 \mu 1$ MICROCARRIER GEL-TR (Molecular Research Center Inc.). The total RNA was identified by a bioanalyzer (Agilent Technologies, Palo Alto, USA) and kept at $-80^{\circ} \mathrm{C}$.

\section{cDNA Synthesis}

RNA was extracted again and was purified with the RQ1 RNase-Free DNase Kit (Promega, Madison, USA). Then, 


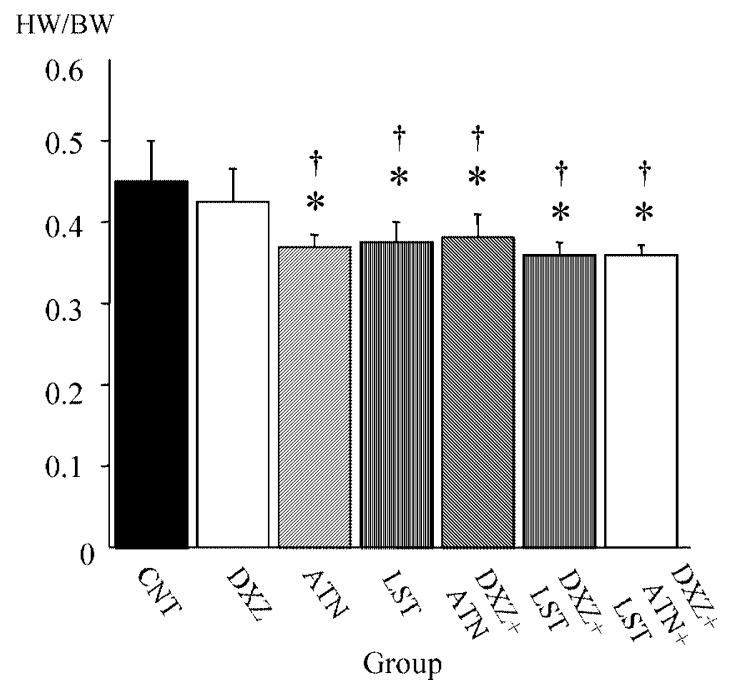

Fig. 1. Heart weight-to-body weight ratio $(H W / B W)$ of untreated spontaneously hypertensive rats (SHR) and SHR treated with monotherapy and combination therapy by doxazosin, atenolol, and/or losartan for 6 weeks. CNT, control; $D X Z$, doxazosin; ATN, atenolol; LST, losartan; DXZ+ATN, combination of doxazosin and atenolol; DXZ+LST, combination of doxazosin and losartan; $D X Z+A T N+L S T$, combination of doxazosin, atenolol, and losartan. The number of animals is indicated in Table 2. ${ }^{*} \mathrm{p}<0.0005$ vs. CNT; ${ }^{\dagger} \mathrm{p}<0.05$ vs. $D X Z$.

cDNA was synthesized from $2 \mu \mathrm{g}$ of the stored total RNA using the First-strand cDNA Synthesis Kit (Amersham Biosciences Co., Pitscataway, USA) and was stored at $-80^{\circ} \mathrm{C}$.

\section{Preparation of Standard cDNA}

PCR amplification was performed for each gene under the conditions shown in Table 1 using the Gene Amp PCR System 9700 (Applied Biosystems) with the Amplitaq Gold for $10 \times$ PCR with a dNTP Kit (Applied Biosystems). After electrophoretic identification, the target band of cDNA was extracted and was purified with the GENECLEAN Kit (Q Biogene, Irvine, USA). The second PCR was performed using the PCR products. The resulting PCR-product was purified using the QIA Quick PCR Purification Kit (QIAGEN, Hilden, Germany), and was identified by electrophoresis. The concentration of the PCR-product was assessed at $260 \mathrm{~nm}$ with a spectroscope (Biotech Ultrospec 2000; Amersham Biosciences Co.), after which the copy number per $\mu 1$ of standard cDNA was calculated and the product was stored at $-80^{\circ} \mathrm{C}$. Before use, RNase-free water was used to prepare a serial dilution of $10^{6}$ copies down to $10^{3}$ copies of each standard cDNA.

\section{Quantitative Real-Time PCR}

Quantitative real-time PCR analysis was carried out using the Gene Amp 5700 Sequence Detection System (Applied Biosystems) with SYBR Green Reagents (Applied Biosystems).

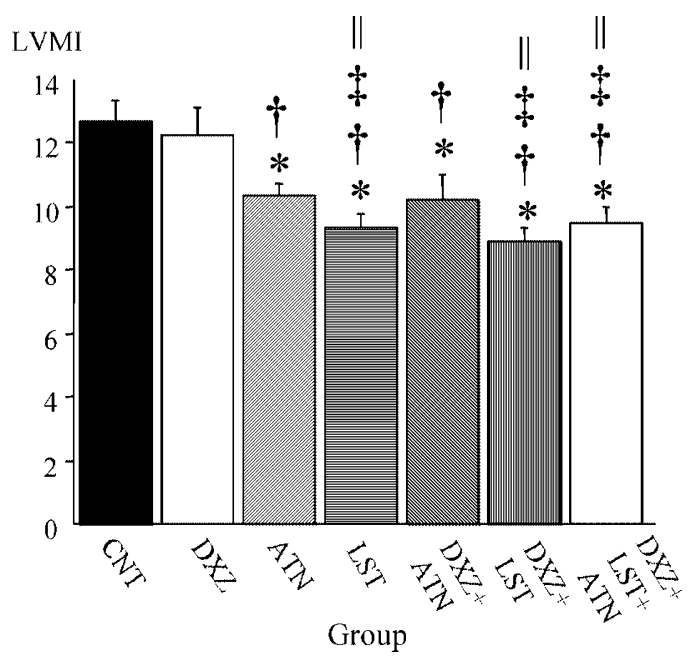

Fig. 2. Left ventricular mass index (LVMI) of untreated spontaneously hypertensive rats (SHR) and SHR treated with monotherapy and combination therapy by doxazosin, atenolol, and/or losartan for 6 weeks. CNT, control; DXZ, doxazosin; ATN, atenolol; LST, losartan; DXZ+ATN, combination of doxazosin and atenolol; DXZ $+L S T$, combination of doxazosin and losartan; DXZ+ATN $+L S T$, combination of doxazosin, atenolol, and losartan. The number of animals is indicated in Table 2. ${ }^{*} \mathrm{p}<0.0001$ vs. CNT; ${ }^{\dagger} \mathrm{p}<0.0001$ vs. $D X Z ;{ }^{\star} \mathrm{p}<0.05$ vs. $A T N ; " \mathrm{p}<0.05$ vs. $D X Z+A T N$.

Amplifications were performed in a $20 \mu \mathrm{l}$ volume containing either the unknown cDNA sample or standard cDNA diluted at each concentration according to the PCR conditions shown in Table 1. An RNA sample not subjected to the reverse transcription reaction was used as a negative control. A nontemplate control was run with every assay, and all determinations were performed at least twice independently so as to achieve reproducibility. The absence of dimer primer formation was verified by the dissociation curve.

At the end of the PCR, the Gene Amp 5700 Sequence Detector System software saved the results for analysis. The number of each mRNA was normalized with that of glyceraldehyde-3-phosphate dehydrogenase (GAPDH), which was used as the internal standard.

\section{Statistical Analysis}

Results are expressed as the mean \pm SEM. All statistical analyses were performed using commercially available statistical software (StatView version 5.0; SAS Institute, Cary, USA). A $p$ value of less than 0.05 was considered statistically significant. One-way factorial ANOVA followed by Student-Newman-Keuls post hoc test was used for multiple comparisons among the groups when a significant difference was present. The $Z$ transformation was used for comparison of correlation coefficients. 
Table 3. Plasma Angiotensin II and Brain Natriuretic Peptide of Untreated Spontaneously Hypertensive Rats (SHR) and SHR Treated with Monotherapy and Combination Therapy by Doxazosin, Atenolol, and/or Losartan for 6 Weeks

\begin{tabular}{|c|c|c|c|c|c|c|c|}
\hline & $\begin{array}{l}\text { CNT } \\
(n=9)\end{array}$ & $\begin{array}{c}\mathrm{DXZ} \\
(n=11)\end{array}$ & $\begin{array}{c}\text { ATN } \\
(n=11)\end{array}$ & $\begin{array}{c}\text { LST } \\
(n=12)\end{array}$ & $\begin{array}{c}\mathrm{DXZ}+\mathrm{ATN} \\
(n=9)\end{array}$ & $\begin{array}{c}\mathrm{DXZ}+\mathrm{LST} \\
(n=11)\end{array}$ & $\begin{array}{c}\mathrm{DXZ}+\mathrm{ATN}+\mathrm{LST} \\
(n=9)\end{array}$ \\
\hline Ang II (pg/ml) & $17.0 \pm 1.71$ & $19.3 \pm 1.76$ & $10.1 \pm 1.09$ & $37.7 \pm 3.96^{*,+, * \pi}$ & $24.2 \pm 5.56$ & $25.3 \pm 5.04$ & $23.2 \pm 4.87$ \\
\hline $\mathrm{BNP}(\mathrm{pg} / \mathrm{dl})$ & $129.1 \pm 18.9$ & $89.1 \pm 10.9 *$ & $87.7 \pm 6.13^{*}$ & $85.0 \pm 7.16^{*}$ & $73.3 \pm 10.8^{*}$ & $77.0 \pm 8.43^{*}$ & $75.1 \pm 12.8^{*}$ \\
\hline
\end{tabular}

Values are expressed as the means \pm SEM. Ang II, angiotensin II; BNP, brain natriuretic peptide; CNT, control; DXZ, doxazosin; ATN, atenolol; LST, losartan; DXZ+ATN, combination of doxazosin and atenolol; DXZ+LST, combination of doxazosin and losartan; $\mathrm{DXZ}+\mathrm{ATN}+\mathrm{LST}$, combination of doxazosin, atenolol, and losartan. ${ }^{*} p<0.05 v s$. CNT; ${ }^{\dagger} p<0.05 v s$. DXZ; ${ }^{*} p<0.05 v s$. ATN; ${ }^{9} p<0.05 v s$. DXZ+LST.

\section{Results}

\section{BW, SBP, and PR}

Table 2 shows the values of BW (g), SBP (mmHg), and PR (beats/min) after the 6 weeks of administration. Food intake, drinking water, and BW during the experimental period did not differ among the groups. The SBP values of the DXZ and LST groups were not significantly different from that of the C group at the end of 1st week of administration (9 weeks of age). However, after the 2nd week of administration, the SBP values of all groups receiving antihypertensive agents were significantly lower than that in the C group $(p<0.001)$, and no significant differences were found among any of the groups receiving drugs. After the 3 rd week, the PR values of all atenolol-administered groups, namely, the ATN, $\mathrm{DXZ}+\mathrm{ATN}$, and DXZ+ATN+LST groups, were significantly lower than those in the C, DXZ, and LST groups $(p<0.05)$. The PR values of the DXZ and LST groups did not differ significantly from that of the $\mathrm{C}$ group during the 6 weeks of the experiment.

\section{HW/BW}

Figure 1 shows the HW/BW values after the 6 weeks of administration. The HW/BW values of the ATN, LST, $\mathrm{DXZ}+\mathrm{ATN}, \mathrm{DXZ}+\mathrm{LST}$, and DXZ+ATN + LST groups were significantly lower than those in the $\mathrm{C}(p<0.0005)$ and DXZ $(p<0.05)$ groups .

\section{LVMI by Echocardiography}

Figure 2 shows the results of LVMI after the 6 weeks of administration. The LVMI values of all drug-receiving groups except the DXZ group (i.e., the ATN, LST, $\mathrm{DXZ}+\mathrm{ATN}, \mathrm{DXZ}+\mathrm{LST}$, and $\mathrm{DXZ}+\mathrm{ATN}+\mathrm{LST}$ groups) were significantly lower than those in the $\mathrm{C}$ and $\mathrm{DXZ}$ groups $(p<0.0001)$. Moreover, the groups receiving losartan (i.e., the LST, DXZ+LST, and DXZ+ATN+LST groups) had significantly lower LVMI than the ATN and DXZ+ATN groups $(p<0.05)$.

\section{pBNP and Angiotensin II}

Table 3 shows the values of pBNP and angiotensin II after the 6 weeks of administration. The pBNP values of all drugreceiving groups were significantly lower than that in the $\mathrm{C}$ group $(p<0.05)$. The level of angiotensin II was significantly higher in the LST group than in the $\mathrm{C}$ group $(p<0.05)$. Moreover, the LST group had a significantly higher level of angiotensin II than the DXZ, ATN, and DXZ+LST groups $(p<0.05)$.

\section{Left Ventricular BNP mRNA Expression}

Figure 3 shows the results of left ventricular BNP mRNA expression according to the quantitative real-time PCR assay. The expressions of left ventricular BNP mRNA were significantly lower in the ATN, LST, and combined-administration groups (i.e., the DXZ+ATN, DXZ+LST, and DXZ+ATN+ LST groups) than in the $\mathrm{C}$ and DXZ groups $(p<0.005)$. They were also significantly lower in the LST and combinedadministration groups than in the ATN group $(p<0.05)$.

\section{Correlation between HW/BW, LVMI, pBNP, and Left Ventricular BNP mRNA Expression}

Figure 4 shows a simple correlation plot of $\mathrm{HW} / \mathrm{BW}$ and LVMI after the 6 weeks of administration $(r=0.720$, $p<0.0001)$. Figure 5A and B show significant positive correlations between LVMI and pBNP $(r=0.305, p=0.0230)$, and between LVMI and left ventricular BNP mRNA expression $(r=0.668, p<0.0001)$ in all rats after 6-week administration. The correlation coefficient between LVMI and left ventricular BNP mRNA expression was significantly stronger than that between LVMI and pBNP $(p<0.05)$. Similarly, HW/BW showed significant positive correlations with pBNP $(r=0.438, p=0.0006)$ and with left ventricular BNP mRNA expression ( $r=0.455, p=0.0004)$ (Fig. 5C and D). However, no significant difference was found in the correlation coefficients of HW/BW with pBNP and of HW/BW with left ventricular BNP mRNA expression. 


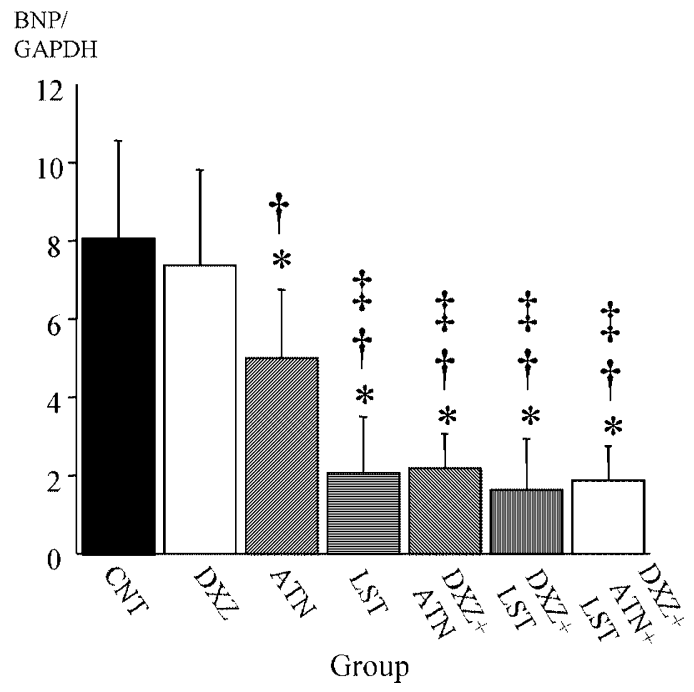

Fig. 3. Brain natriuretic peptide (BNP) $m R N A$ expression in the left ventricle of untreated spontaneously hypertensive rats (SHR) and SHR treated with monotherapy and combination therapy by doxazosin, atenolol, and/or losartan for 6 weeks. GAPDH, glyceraldehyde-3-phosphate-dehydrogenase; CNT, control; DXZ, doxazosin; ATN, atenolol; LST, losartan; $D X Z+A T N$, combination of doxazosin and atenolol; $D X Z+L S T$, combination of doxazosin and losartan; $D X Z+A T N+L S T$, combination of doxazosin, atenolol, and losartan. BNP $m R N A$ level is corrected for $m R N A$ of GAPDH and is expressed as the ratio of BNP $M R N A$ to GAPDH. The number of animals is indicated in Table 2. ${ }^{*} \mathrm{p}<0.05$ vs. $C N T$; ${ }^{\dagger} \mathrm{p}<0.005$ vs. $D X Z ;{ }^{\star} \mathrm{p}<0.005$ vs. $A T N$.

\section{Discussion}

\section{Heart Weight, LVMI, pBNP, and Left Ventricular BNP mRNA Expression as Indices of Cardiac Hypertrophy}

A clear positive correlation was found between heart weight and LVMI, verifying the usefulness of this parameter as an index of cardiac hypertrophy. Moreover, LVMI was correlated with pBNP and with left ventricular BNP mRNA expression. A stronger positive correlation was found between LVMI and left ventricular BNP mRNA expression than between LVMI and plasma BNP.

The main source of $\mathrm{pBNP}$ is the cardiac ventricle, and a smaller proportion is derived from the atrium. Whereas BNP is synthesized and secreted immediately following stimulation in the atrium, in the cardiac ventricle it is secreted after being stored in the secretory granules (26-28). Therefore, pBNP reflects not only the immediate response in the atrium but also chronic overload in the left ventricle. Therefore, it is possible that the expression of left ventricle-localized BNP mRNA more accurately reflects morphological changes of the heart.

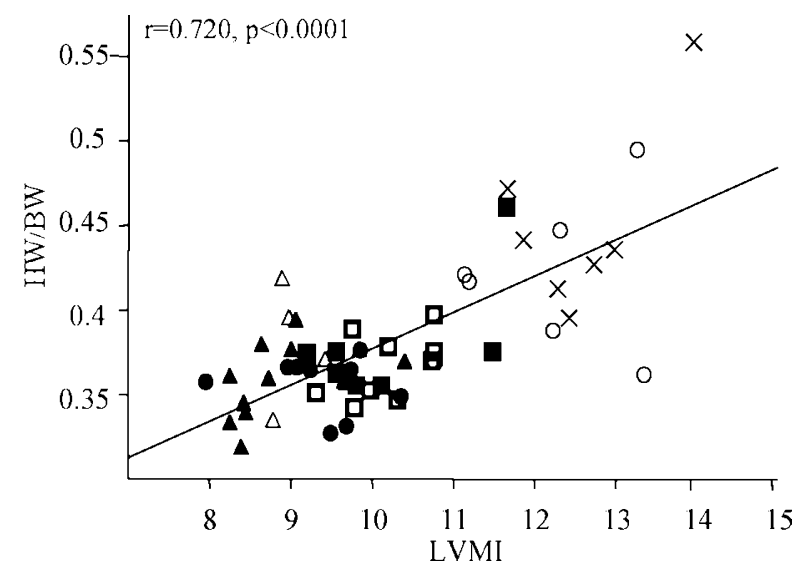

Fig. 4. Correlation between left ventricular mass index (LVMI) and heart weight-to-body weight ratio $(\mathrm{HW} / \mathrm{BW})$ in all spontaneously hypertensive rats after the 6-week experimental period. The number of animals is indicated in Table 2. $H W / B W$ is positively correlated with LVMI $(\mathrm{r}=0.720$, $\mathrm{p}<0.0001) . \times, C N T$ (control); $\mathrm{O}, D X Z$ (doxazosin); $\square, A T N$ (atenolol); $\triangle, L S T$ (losartan); $\mathbf{\square}, D X Z+A T N$ (combination of doxazosin and atenolol); $\mathbf{\Delta}, D X Z+L S T$ (combination of doxazosin and losartan); $\bullet, D X Z+A T N+L S T$ (combination of doxazosin, atenolol, and losartan).

\section{Analysis of Monotherapy}

In the DXZ group, pBNP fell, but left ventricular BNP mRNA expression did not decrease without suppression of cardiac hypertrophy. The exact reason for this discrepancy is not clear. There have been other reports that the expression of BNP mRNA in the left ventricle reflects left ventricular hypertrophy (29). Also, it has been reported that pBNP increases in proportion to cardiac overload (30). Therefore, it may be that in the case of monotherapy with the $\alpha 1$ adrenergic receptor blocker, reduction of blood pressure strongly suppresses BNP derived from other chambers compared to BNP from the left ventricle. Moreover, it is possible that during the lowering of blood pressure by the $\alpha 1$ adrenergic receptor blocker, adrenergic receptor agonists increased by feedback mechanisms exert an effect on $\beta$ receptors and obscure its cardiac antihypertrophic effect. On the other hand, a previous clinical study reported that doxazosin did not prevent heart failure in hypertensive patients (31), and this finding may have some relation to the present result that BNP mRNA was not suppressed in the left ventricle in the $\mathrm{DXZ}$ group.

Heart weight, LVMI, pBNP, and left ventricular BNP mRNA expression all declined in the LST and ATN groups, indicating that both drugs are effective in suppressing the development of hypertensive left ventricular hypertrophy. Furthermore, LVMI and left ventricular BNP mRNA expression in the LST group were lower than those in the ATN group. Therefore, losartan may be superior to atenolol in suppressing hypertensive left ventricular hypertrophy. It is 
(A)

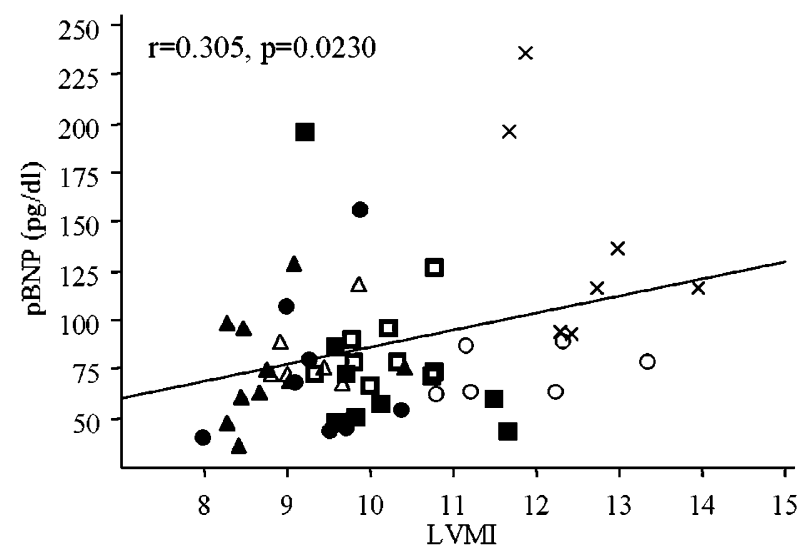

(C)

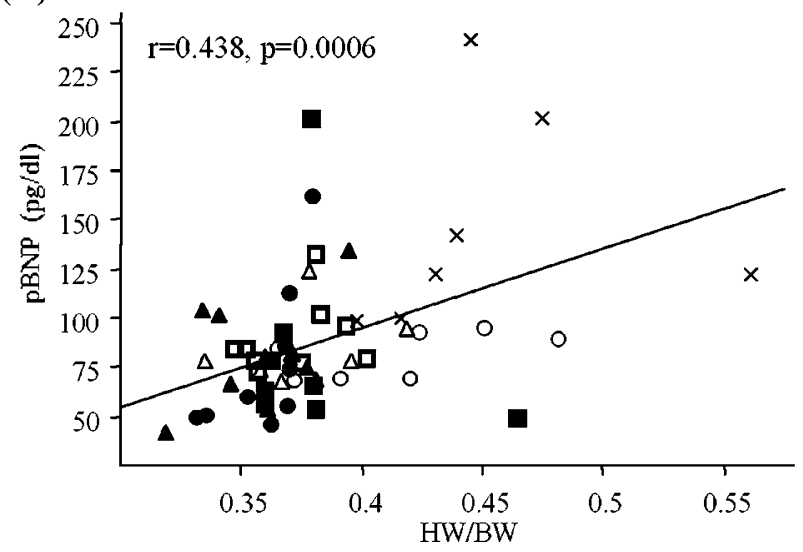

(B)

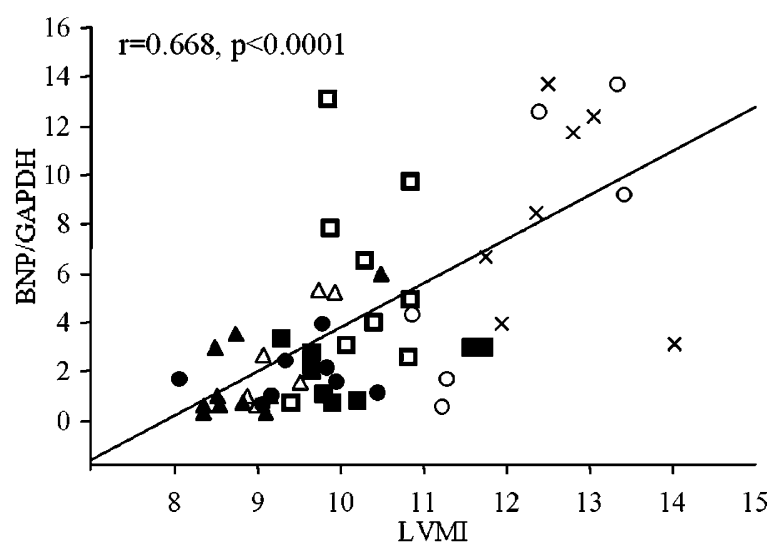

(D)

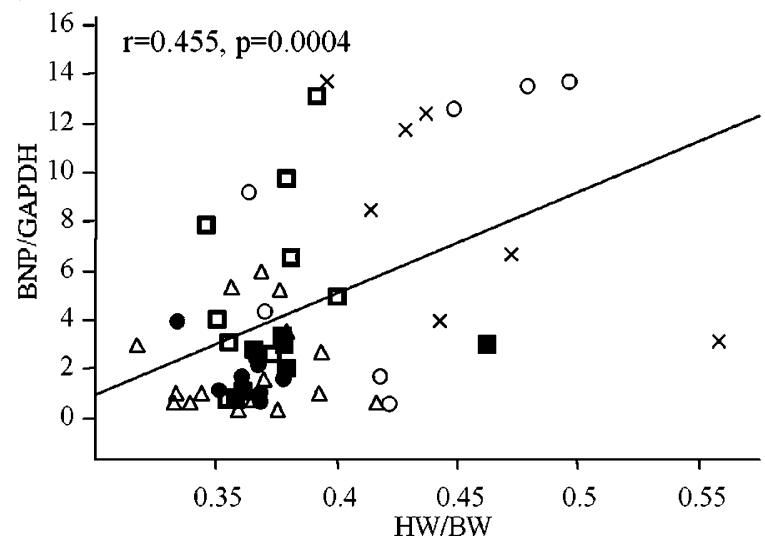

Fig. 5. Correlation of left ventricular mass index (LVMI), heart weight-to-body weight ratio (HW/BW), plasma BNP ( $p B N P)$, and left ventricular BNP $m R N A$ expression in all spontaneously hypertensive rats after the 6-week experimental period. BNP, brain natriuretic peptide; GAPDH, glyceraldehyde-3-phosphate-dehydrogenase. $\times$, CNT (control); $\bigcirc, D X Z$ (doxazosin); $\square$,

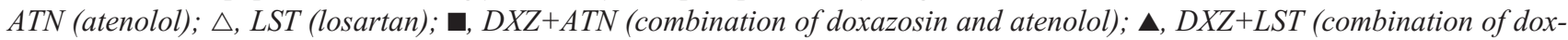
azosin and losartan); $\bullet, D X Z+A T N+L S T$ (combination of doxazosin, atenolol, and losartan). The BNP $m R N A$ level is corrected for $m R N A$ of GAPDH and is expressed as the ratio of BNP $m R N A$ to GAPDH. The number of animals is indicated in Table 2. A: LVMI is positively correlated with $p B N P(\mathrm{r}=0.305, \mathrm{p}=0.0230)$. B: LVMI is positively correlated with left ventricular BNP $m R N A(\mathrm{r}=0.668, \mathrm{p}<0.0001) . C: H W / B W$ is positively correlated with $p B N P(\mathrm{r}=0.438, \mathrm{p}=0.0006) . D: H W / B W$ is positively correlated with left ventricular $B N P$ mRNA $(\mathrm{r}=0.455, \mathrm{p}=0.0004)$.

possible that a slight difference in blood pressure lowering influenced suppression of cardiac hypertrophy. However, according to the results of this study, the class of drugs, rather than the degree of reduction in blood pressure, makes the major contribution to the difference in suppression of cardiac hypertrophy. A similar antihypertrophic effect of losartan was also observed clinically as cardiovascular morbidity and mortality in the Losartan Intervention for Endpoint Reduction in Hypertension (LIFE) study (32).

\section{Analysis of Monotherapy and Combination Ther- apy of Adrenergic Receptor Blockers}

No obvious left ventricular antihypertrophic effect was found by doxazosin monotherapy, but doxazosin was effective in combination with atenolol. It has been reported that collagen mRNA expression and heart weight were significantly lower in SHR receiving combination therapy with doxazosin and atenolol than in those receiving doxazosin monotherapy, although the blood pressure reduction was comparable (33). Yamori et al. reported that hypertension and cardiac hypertrophy occurred with continuous infusion of norepinephrine in SHR, and although blood pressure decreased with simultaneous administration of the $\alpha 1$ adrenergic receptor blocker, the heart weights of the animals increased (34). They also found that even though the blood pressure-reducing effect of the $\beta$ adrenergic receptor blocker was less than that of the $\alpha 1$ blocker, the increase of heart weight was inhibited by the $\beta$ 
adrenergic receptor blocker. It is possible that stimulation of $\beta$ adrenergic receptors is more closely related to the development of cardiac hypertrophy than is stimulation of $\alpha 1$ receptors in SHR.

Since left ventricular BNP mRNA expression by combination therapy with doxazosin and atenolol was significantly lower than that by atenolol monotherapy, the antihypertrophic effects may be enhanced when $\alpha 1$ and $\beta$ adrenergic receptor antagonists are combined. Similarly, it has been reported that administration of carvedilol, which is an $\alpha \beta$ adrenergic receptor antagonist, inhibits the development of cardiac hypertrophy in SHR (35). It has been indicated that $\alpha 1$ adrenergic receptor blockers reduce the unfavorable effect of $\beta$ blockers on insulin sensitivity and lipid metabolism (36). Based on our present results, a combination therapy with adrenergic receptor antagonists might be more effective in preventing hypertensive organ damage than monotherapy with either the $\alpha 1$ or the $\beta$ adrenergic receptor antagonist.

\section{Analysis of Combination Therapies of ARB and Adrenergic Receptor Antagonists}

In this study, heart weight, LVMI, pBNP, and left ventricular BNP mRNA expression were decreased in the groups receiving losartan. Furthermore, there was no significant difference in inhibition of the development of left ventricular hypertrophy between the combination therapies of losartan and adrenergic receptor antagonists and losartan monotherapy. This result indicates that RAS plays an important role in the development of cardiac hypertrophy. This superior effect of the ARB may be partly related to its sympathetic nerve-suppressing effect through AT1 receptors, as reported previously (37). However, there was no significant change in heart rate among the losartan-treated groups in the present study. This may have been because suppression of SNS by the ARB is an indirect effect, whereas that by the $\beta$ adrenoceptor antagonist is a direct effect on $\beta$ adrenergic receptors. The parasympathetic nervous system also influences heart rate, and thus the change in heart rate may not have been pronounced in the losartantreated groups.

Since all drug-receiving groups displayed comparable antihypertensive effects in the present study, the left ventricular antihypertrophic effects observed with losartan may be related, at least to some degree, to mechanisms not dependent on blood pressure-lowering effects. There have been two reports of cardiac antihypertrophic effects by angiotensin converting enzyme inhibitors and ARBs even in doses that do not influence blood pressure $(38,39)$. Plasma catecholamines increase during administration of doxazosin by the feedback mechanism and may stimulate $\beta$ adrenergic receptors. By combining doxazosin with atenolol, it is possible to avoid this influence on $\beta$ adrenergic receptors. Therefore, it is expected that doxazosin works effectively in combination with atenolol. However, in the present study doxazosin was more effective in suppressing cardiac hypertrophy when given in combination with losartan than when combined with atenolol.

Although the combination of atenolol and losartan was not administered in this study, addition of atenolol to the combination of doxazosin and losartan did not lead to any obvious difference compared to the combination of doxazosin and losartan. Therefore, it can be inferred that the cardiac antihypertrophic effects of atenolol and losartan in combination will not be significantly greater than other combination therapies.

In conclusion, the ARB was shown to suppress hypertensive cardiac hypertrophy in SHR more effectively than adrenergic receptor antagonists. With respect to the $\alpha 1$ and $\beta$ adrenergic receptor antagonists, they were more effective in combination than when administered singly, under comparable antihypertensive effects in SHR.

\section{Aknowledgements}

Doxazosin and losartan were kindly donated by Pfizer Inc. (New York, USA) and Banyu Pharmaceutical Co., Ltd. (Tokyo, Japan), respectively. We also thank Ms. Mika Watanabe and Ms. Fumie Anzai for their expert technical assistance.

\section{References}

1. Levy D, Garrison RJ, Savage DD, Kannel WB, Castelli WP: Prognostic implications of echocardiographically determined left ventricular mass in Framingham heart study. $N$ Engl J Med 1990; 322: 1561-1566.

2. Komuro I, Yazaki Y: Control of cardiac gene expression by mechanical stress. Annu Rev Physiol 1993; 55: 55-57.

3. Morgan HE, Baker KM: Cardiac hypertrophy. Mechanical, neural, and endocrine dependence. Circulation 1991; 83: 13-25.

4. Yamazaki T, Komuro I, Zou Y, et al: Norepinephrine induced the raf-1 kinase/mitogen-activated protein kinase cascade through both $\alpha 1$ - and $\beta$-adrenoceptors. Circulation 1997; 95: 1260-1268.

5. Goldstein DS: Plasma catecholamines and essential hypertension. An analytical review. Hypertension 1983; 5: 86-99.

6. Beker KM, Chernin MI, Wixson SK, Aceto JF: Renin-angiotensin system involvement in pressure-overload cardiac hypertrophy in rats. Am J Physiol Heart Circ Physiol 1990; 259: H324-H332.

7. Schunkert H, Dzau VJ, Tang SS, Hirsch AT, Apstein CS, Lorell BH: Increased rat cardiac angiotensin converting enzyme activity and mRNA expression in pressure overload left ventricular hypertrophy. Effects on coronary resistance, contractility, and relaxation. J Clin Invest 1990; 86: 19131920.

8. Dang A, Zheng D, Wang B, et al: The role of renin-angiotensin and cardiac sympathetic nervous systems in the development of hypertension and left ventricular hypertrophy in spontaneously hypertensive rats. Hypertens Res 1999; 22: 217-221.

9. Simpson P: Norepinephrine-stimulated hypertrophy of cultured rat myocardial cells is an alpha 1 adrenergic response. J Clin Invest 1983; 72: 732-738.

10. Huang MH, Friend DS, Sunday ME, et al: An intrinsic ad- 
renergic system in mammalian heart. J Clin Invest 1996; 98: 1298-1303.

11. Crabos M, Roth M, Hahn AW, Erne P: Characterization of angiotensin II receptors in cultured adult rat cardiac fibroblasts. Coupling to signaling systems and gene expression. $J$ Clin Invest 1994; 93: 2372-2378.

12. Sano H, Okamoto H, Kitabatake A, Iizuka K, Murakami T, Kawaguchi $\mathrm{H}$ : Increased mRNA expression of cardiac renin-angiotensin system and collagen synthesis in spontaneously hypertensive rats. Mol Cell Biochem 1998; 178: 5158.

13. Griendling KK, Murphy TJ, Alexander RW: Molecular biology of the renin-angiotensin system. Circulation 1993; 87: $1816-1828$.

14. Arita M, Horinaka S, Komatsu K, Frohlich ED: Reversal of left ventricular hypertrophy with different classes of drugs causes differing ventricular biochemical changes. J Hypertens 1993; 11 (Suppl 5): S354-S355.

15. Brilla CG: Regression of myocardial fibrosis in hypertensive heart disease: diverse effects of various antihypertensive drugs. Cardiovasc Res 2000; 46: 324-331.

16. Varagic J, Susic D, Frohlich ED: Low-dose ACE with alphaor beta-adrenergic receptor inhibitors have beneficial SHR cardiovascular effects. J Cardiovasc Pharmachol Ther 2001; 6: $57-63$

17. Ohta K, Kim S, Iwao H: Role of angiotensin-converting enzyme, adrenergic receptors, and blood pressure in cardiac gene expression of spontaneously hypertensive rats during development. Hypertension 1996; 28: 627-634.

18. Takeda T, Kohno M: Brain natriuretic peptide in hypertension. Hypertens Res 1995; 18: 259-266.

19. Nakagawa O, Ogawa Y, Itoh H, et al: Rapid transcriptional activation and early mRNA turnover of brain natriuretic peptide in cardiocyte hypertrophy. Evidence for brain natriuretic peptide as an "emergency" cardiac hormone against ventricular overload. J Clin Invest 1995; 96: 1280-1287.

20. Suzuki M, Hamada M, Yamamoto K, Kazatani Y, Hiwada $\mathrm{K}$ : Brain natriuretic peptide as a risk marker for incident hypertensive cardiovascular events. Hypertens Res 2002; 25: 669-676.

21. Maeso R, Navarro-Cid J, Rodrigo E, Ruilope LM, Lahera V, Cachofeiro V: Differential effects of losartan and doxazosin on vascular function in senescent spontaneously hypertensive rats. Am J Hypertens 1999; 12: 1105-1108.

22. Haneda T, Ogawa Y, Kato J, et al: Effect of celiprolol on cardiac hypertrophy in hypertension. Hypertens Res 2000; 23: 467-474.

23. Devereux RB, Alonso DR, Lutas EM, et al: Echocardiographic assessment of left ventricular hypertrophy: comparison to necropsy findings. Am J Cardiol 1986, 57: 450-458.

24. Brown LB, Nunez DJR, Wilkins MR: Differential regulation of natriuretic peptide receptor messenger RNAs during development of cardiac hypertrophy in the rat. J Clin Invest 1993; 92: 2702-2712.

25. Terada Y, Tomita K, Nonoguchi H, Marumo F: Polymerase chain reaction localization of constitutive nitric oxide synthase and soluble guanylate cyclase messenger RNAs in microdissected rat nephron segments. J Clin Invest 1992; 90: 659-665.

26. Ogawa Y, Nakao K, Mukoyama M, et al: Natriuretic pep- tides as cardiac hormones in normotensive and spontaneously hypertensive rats. The ventricle is a major site of synthesis and secretion of brain natriuretic peptide. Circ Res 1991; 69: 491-500.

27. Mukoyama M, Nakao K, Hosoda K, et al: Brain natriuretic peptide as a novel cardiac hormone in humans. Evidence for an exquisite dual natriuretic peptide system, atrial natriuretic peptide and brain natriuretic peptide. J Clin Invest 1991; 87: 1402-1412.

28. Magga J, Marttila M, Mantymaa P, Vuolteenaho O, Ruskoaho $\mathrm{H}$ : Brain natriuretic peptide in plasma, atria, and ventricles of vasopressin- and phenylephrine-infused conscious rats. Endocrinology 1994; 134: 2505-2515.

29. Magga J, Kalliovalkama J, Romppanen H, et al: Differential regulation of cardiac adrenomedullin and natriuretic peptide gene expression by AT1 receptor antagonism and ACE inhibition in normotensive and hypertensive rats. J Hypertens 1999; 17: 1543-1552.

30. Yokota N, Aburaya M, Yamamoto Y, et al: Increased plasma brain natriuretic peptide levels in DOCA-salt hypertensive rats: relation to blood pressure and cardiac concentration. Biochem Biophys Res Commun 1990; 173: 632-638.

31. ALLHAT Officers and Coordinators for the ALLHAT Collaborative Research Group: Diuretic versus $\alpha$-blocker as first-step antihypertensive therapy: final results from the antihypertensive and lipid-lowering treatment to prevent heart attack trial (ALLHAT). Hypertension 2003; 42: 239246.

32. Dahlof B, Devereux RB, Kjeldsen SE, et al: Cardiovascular morbidity and mortality in the losartan intervention for endpoint reduction in hypertension study (LIFE): a randomised trial against atenolol. Lancet 2002; 359: 995-1003.

33. Ohta K, Kim S, Iwao H: Role of angiotensin-converting enzyme, adrenergic receptors, and blood pressure in cardiac gene expression of spontaneously hypertensive rats during development. Hypertension 1996; 28: 627-634.

34. Yamori Y, Tarazi RC, Ooshima A: Effect of beta-receptorblocking agents on cardiovascular structural changes in spontaneous and noradrenaline-induced hypertension in rats. Clin Sci (Lond) 1980; 59 (Suppl 6): 457s-460s.

35. Ohlstein EH, Vickery L, Arleth A, et al: Carvedilol, a novel cardiovascular agent, inhibits development of vascular and ventricular hypertrophy in spontaneously hypertensive rats. Clin Exp Hypertens 1994; 16: 163-177.

36. Lithell H, Aberg H, Selinus I: Metabolic effects of a change in antihypertensive treatment. Am J Med 1986; 80: 114-119.

37. Bezerra SM, dos Santos CM, Moreira ED, Krieger EM, Michelini LC: Chronic AT1 receptor blockade alters autonomic balance and sympathetic responses in hypertension. Hypertension 2001; 38: 569-575.

38. Pinto YM, Pinto-Sietsma SJ, Philipp T, et al: Reduction in left ventricular messenger RNA for transforming growth factor $\beta 1$ attenuates left ventricular fibrosis and improves survival without lowering blood pressure in the hypertensive TGR(mRen2)27 rat. Hypertension 2000; 36: 747-754.

39. Linz W, Schaper J, Wiemer G, Albus U, Scholkens BA: Ramipril prevents left ventricular hypertrophy with myocardial fibrosis without blood pressure reduction: a one year study in rats. Br J Pharmacol 1992; 107: 970-975. 